\title{
The assessment of the prediction capacity of abdominal striae gravidarum on intraabdominal adhesions in the pregnant women with the history of cesarean section evaluated before the cesarean section
}

\author{
ilknur Çöl Madendağ (D), Mefkure Eraslan Şahin (ID \\ Clinic of Gynecology and Obstetrics, Kayseri City Hospital, Kayseri, Turkey
}

\begin{abstract}
Objective: The clinical and ultrasonographic examinations are performed in order to predict the presence or the severity of intraabdominal adhesion before the operation. By determining the severity of adhesion before the operation, it is possible to prevent intraoperative surgical complications. Considering that the development of striae gravidarum is associated with the development of connective tissue and collagen, we aimed in our study to assess the prediction capacity of striae gravidarum on the intraabdominal adhesions by evaluating the presence and severity of abdominal striae gravidarum before the cesarean section in the pregnant women with the history of cesarean section.

Methods: The pregnant women who admitted within 6 months were included in this prospective cross-sectional study carried out in a tertiary center. Maternal age, body mass index, total weight gained during pregnancy, the presence of pregestational or gestational diabetes, habit of smoking, presence of chronic systemic disease, the number of previous cesarean section, newborn birth weight and current week of gestation, fetal weight and fetal sex were recorded. The severity of striae gravidarum was determined according to Davey's scoring system. Intraabdominal peritoneal adhesions were evaluated according to the modified Nair scoring system. Three groups were established according to the severity of striae gravidarum.

Results: Remaining 378 patients after the exclusion criteria were compared in 3 groups. There was no difference between the groups in terms of their demographic characteristics. No statistically significant correlation was found between the severities of striae gravidarum and peritoneal adhesion $(\mathrm{p}=0.401)$. Also, there was no significant correlation between striae gravidarum and the scar appearance types $(\mathrm{p}=0.215)$ and the presence of keloid $(\mathrm{p}=0.127)$.

Conclusion: We think that the score of striae gravidarum is not correlated with keloid and scar appearance, it will be an unsuccessful marker for the prediction of peritoneal adhesions and that it will have low specificity values even it is used.
\end{abstract}

Keywords: Striae gravidarum, peritoneal adhesions, pregnancy, cesarean section, scar.

\begin{abstract}
Özet: Sezaryen hikâyesi bulunan gebelerde sezaryen öncesi değerlendirilen abdominal striae gravidarum seviyesinin intraabdominal yapışıklıkları öngörebilirliğinin değerlendirilmesi

Amaç: Operasyon öncesi intraabdominal yapışıklık olup olmadığını veya yapışıklığın şiddetini öngörebilmek amacıyla klinik ve ultrasonografik araştırmalar yapılmaya devam etmektedir. Operasyon öncesi yapışıklığın şiddetinin tespiti ile intraoperatif cerrahi komplikasyonları önlemek mümkün olacaktır. Striae gravidarum gelişiminin bağ dokusu ve kollajen gelişimi ile ilişkili olduğu düşünüldüğünde mevcut çalışmada sezaryen hikayesi bulunan gebelerde sezaryen öncesi abdominal striae gravidarum varlığını ve şiddetini değerlendirerek striae gravidarumun intraabdominal yapışıklıkları öngörebilirliğini değerlendirmeyi amaçladık.

Yöntem: Tersiyer bir merkezde prospektif kesitsel bir çalışma olarak 6 ay süre içinde başvuran gebeler çalışmaya dahil edildi. Maternal yaş, vücut kitle indeksi, gebelikte alınan toplam kilo mikta$\mathrm{r} 1$, pregestasyonel veya gestasyonel diyabet varlığ 1 , sigara kullanımı, kronik sistemik hastalık varlığı, geçirilmiş sezaryen sayısı ve bebek doğum ağırlıkları ile mevcut gebelikteki doğum haftası, fetal ağırlık ve fetal cinsiyet kaydedildi. Striae gravidarum şiddeti Davey skorlama sistemi ile belirlendi. İntraabdominal peritoneal adezyonlar modifiye Nair skorlama sistemine göre değerlendirildi. Striae gravidarum şiddetine göre 3 grup oluşturuldu.

Bulgular: Dışlama kriterleri sonrası kalan 378 hasta 3 grup olarak karşılaştırıldı. Gruplar arasında demografik özellikler açısından fark yoktu. Striae gravidarum şiddeti ile peritoneal adezyon şiddeti arasında istatistiksel olarak bir ilişki bulunamadı $(\mathrm{p}=0.401)$. Ayrıca skar görünüm tipleri $(\mathrm{p}=0.215)$ ve keloid varlığ $1(\mathrm{p}=0.127)$ ile striae gravidarum arasında da anlamlı bir ilişki yoktu.

Sonuç: Striae gravidarum skorunun keloid ve skar görünümü ile ilişkisiz olduğu, peritoneal adezyonları önceden tahmin etmede başarısız bir belirteç olacağı, kullanılsa dahi çok düşük özgüllük değerlerine sahip olacağı görüşündeyiz.
\end{abstract}

Anahtar sözcükler: Striae gravidarum, peritoneal adezyonlar, gebelik, sezaryen, skar.

Correspondence: İlknur Çöl Madendă̆, MD. Clinic of Gynecology and Obstetrics, Kayseri City Hospital, Kayseri, Turkey.

e-mail: ilknurmadendag@gmail.com / Received: November 18, 2019; Accepted: December 21, 2019

Please cite this article as: Çöl Madendă İ, Eraslan Şahin M. The assessment of the prediction capacity of abdominal striae gravidarum on intraabdominal adhesions in the pregnant women with the history of cesarean section evaluated before the cesarean section. Perinatal Journal 2019;27(3):150-154. doi:10.2399/prn.19.0273005 


\section{Introduction}

Striae gravidarum (SG) are the linear bands formed as a result of the structural changes in the connective tissue which is observed frequently during pregnancy and disturbs much cosmetically. ${ }^{[1,2]}$ They are seen mostly in the late months of the pregnancy and characterized by the slightly hollow reddish scars which are located on abdominal skin mostly. ${ }^{[1,2]}$ The exact reason of the formation of striae is not known. Genetic factors, hormonal changes during pregnancy and the increase of lateral tension on connective tissue due to increased regional distention are discussed in its etiopathogenesis. ${ }^{[3]}$ The prevalence vary between $50 \%$ and $90 \% .{ }^{[4]}$ Although various studies have reported that the creams applied during pregnancy prevent striae, there is no certain treatment to prevent their formation. ${ }^{[2-4]}$

The rates of cesarean section have been increasing nowadays and intraabdominal adhesions develop after each abdominal operation. The reoperations due to intraabdominal adhesions are usually challenging, and their complication rates are high. ${ }^{[5]}$ Today, clinical and ultrasonographic examinations are carried out to predict the presence or severity of intraabdominal adhesion before the operation. It will be possible to prevent intraoperative surgical complications with the determination of the severity of adhesion before the operation.

Considering that the development of SG is associated with the development of connective tissue and collagen, we aimed in our study to assess the prediction capacity of SG on the peritoneal adhesions by evaluating the presence and severity of abdominal SG before the cesarean section in the pregnant women with the history of cesarean section.

\section{Methods}

This cross-sectional study was conducted prospectively in the Clinic of Gynecology and Obstetrics at Kayseri City Hospital. The study approval was obtained from the Ethics Committee of the Faculty of Medicine, Erciyes University (2019/721). All steps of the study were performed in accordance with the Declaration of Helsinki. The pregnant women who admitted to our clinic for the cesarean section between April 2019 and September 2019 and met the following criteria were included in the study: the pregnant women whose ethnic origin was Turkish, who were at above 37 weeks of gestation, in the age range of 20-35, had singleton pregnancy and underwent cesarean section only once. The patients with the history of pelvic inflammatory disease, abdomino-pelvic surgery and endometriosis apart from the cesarean section were excluded from the study as these conditions might cause additional adhesion. In addition, the patients who had surgical site infection and the history of steroid use which might cause the formation of SG during pregnancy were also excluded from the study. Maternal age, body mass index (BMI), total weight gained during pregnancy, the presence of pregestational or gestational diabetes, habit of smoking, presence of chronic systemic disease, the number of previous cesarean section, newborn birth weight and current week of gestation, fetal weight and fetal sex were recorded. The cases who underwent previous cesarean section less than 2 years ago, obese cases with BMI over 30 , those who gained more than $20 \mathrm{~kg}$ during pregnancy, the cases who underwent any local treatment for SG, those who had vaginal delivery previously, the cases who smoke, those who had a history of diabetes mellitus, chronic systemic diseases or connective tissue diseases were excluded from the study. Of the patients, those who underwent Pfannenstiel incision on their abdomen and Kerr incision on their uterine in their previous cesarean section were included in the study.

The presence and severity of striae in the pregnant women were determined by Davey's scoring system which was used in the previous studies. ${ }^{[6]}$ The abdomen was separated into 4 horizontal and vertical quadrants, and each quadrant received a score. The absence of striae in a single quadrant meant 0 point, presence of $1-3$ striae meant 1 point, and 4 or more striae meant 2 points. Then, the scores of 4 quadrants were added up and total score was obtained. The patients with no stria were included in the group of "no stria". The patients with the total striae score of 1 or 2 were included in the group of "mild striae", and those with the scores of 3 to 8 were included in the group of "severe striae". All striae which were in the form of reddish, shiny and silvery lines in the abdominal skin examination were included in the count.

Intraabdominal peritoneal adhesions during surgery were evaluated according to the modified Nair scoring system. ${ }^{[7]}$ According to this system, following definitions were made: grade $0=$ no adhesion in the intraabdominal examination; grade 1 = the presence of single band 
between visceral surface of uterine and abdominal wall; grade 2 = the presence of two bands between visceral surface of uterine and abdominal wall; grade $3=$ the presence of more than two bands between visceral surface of uterine and abdominal wall; and grade $4=$ the cases where uterine surface is directly adhered to the anterior abdominal wall.

The modified Nair scoring system was used to understand the relation between abdominal striae and adhesion scoring system. According to this modified classification system, grade 1 or 2 was defined as film-like (membranous) in the presence of abdominal adhesion and grade 3 or 4 was defined as dense in the presence of abdominal adhesion. ${ }^{[8]}$ Three groups were established in the study, and they were classified as "no stria", "mild striae", and "severe striae". The skin was defined as smooth, hollow and high according to the scar appearance. Also, the presence of keloid was also recorded. The relationship between the severity of striae gravidarum and the severity of peritoneal adhesion was assessed.

\section{Statistical analysis}

The data of this study were processed and compared by using PASW statistics software version 18 (SPPS, Inc.; Chicago, IL, USA). In order to determine the normality of the data, Shapiro-Wilk test was used to compare two groups, and Levene's test was used to test the homogeneity of the variants. For the continuous variables, the groups were compared by using either Student's t-test or Mann-Whitney U test. The cate- gorical variables were compared by using either chisquare test or Fisher's exact test. For the multi-group comparison of continuous variables, one-way ANOVA and Kruskal-Wallis variance analysis were used. The value of $\mathrm{p}<0.05$ was considered statistically significant.

\section{Results}

A total of 568 patients were included in the study. Of them, 190 were excluded from the study due to the exclusion criteria. Of the remaining 378 patients, 186 were included in the Group 1 (no stria), 82 were included in the Group 2 (mild striae), and 110 were included in the Group 3 (severe striae). There was no significant difference between the groups in terms of the demographic characteristics such as age, gravida, abortus rates, education level, income level, being a housewife, mean weight gained during pregnancy, weeks of gestation, fetal sex and newborn birth weight. Continuous variables and categorical variables of the maternal characteristics are shown in Table $\mathbf{1}$.

The comparisons of the groups in terms of peritoneal adhesions, the presence of keloid, the scar appearance types of cesarean section on skin and the presence of abdominal striae are presented in Table 2. Accordingly, no statistically significant correlation was found between the severity of striae gravidarum and peritoneal adhesions $(\mathrm{p}=0.401)$. Also, there was no significant correlation between the stria gravidarum and scar appearance types $(\mathrm{p}=0.215)$ and the presence of keloid $(\mathrm{p}=0.127)$.

Table 1. The comparison of the groups in terms of the demographic characteristics.

\begin{tabular}{|c|c|c|c|c|}
\hline & $\begin{array}{c}\text { Group } 1 \text { ( } n=186) \\
\text { No stria }\end{array}$ & $\begin{array}{l}\text { Group } 2 \text { ( } n=82) \\
\text { Mild striae }\end{array}$ & $\begin{array}{c}\text { Group } 3(n=110) \\
\text { Severe striae }\end{array}$ & p-value \\
\hline Age (year) & $25.3 \pm 4.5$ & $26.1 \pm 4.5$ & $25.9 \pm 3.9$ & 0.245 \\
\hline $\mathrm{BMI}\left(\mathrm{kg} / \mathrm{m}^{2}\right)$ & $25.1 \pm 3.2$ & $24.9 \pm 3.9$ & $25.3 \pm 3.5$ & 0.257 \\
\hline Weight gained during pregnancy & $12.2 \pm 4.7$ & $13.0 \pm 2.9$ & $12.9 \pm 4.2$ & 0.348 \\
\hline Gravida & $2.2 \pm 0.5$ & $2.3 \pm 0.4$ & $2.1 \pm 0.5$ & 0.656 \\
\hline Abortus & $0.3 \pm 0.5$ & $0.4 \pm 0.5$ & $0.4 \pm 0.5$ & 0.511 \\
\hline Educational status (university) & $33(18 \%)$ & $13(16 \%)$ & $15(14 \%)$ & 0.189 \\
\hline Unemployed & $98(53 \%)$ & $48(59 \%)$ & $67(61 \%)$ & 0.201 \\
\hline Income level (>8,000 TRL /month) & $39(21 \%)$ & $14(17 \%)$ & $16(15 \%)$ & 0.177 \\
\hline Newborn birth weight (g) & $3300 \pm 283$ & $3250 \pm 293$ & $3290 \pm 310$ & 0.355 \\
\hline Fetal sex (girl) & $89(48 \%)$ & $38(47 \%)$ & $53(48 \%)$ & 0.654 \\
\hline Week of gestation at delivery & $38.6 \pm 1.1$ & $38.5 \pm 1.0$ & $39.0 \pm 1.2$ & 0.103 \\
\hline
\end{tabular}

BMI: Body mass index; TRL: Turkish Lira. The values are given as mean \pm standard deviation and $\mathrm{n}(\%)$. 
Table 2. The comparison of the groups in terms of peritoneal adhesions and some scar characteristics.

\begin{tabular}{|c|c|c|c|c|c|}
\hline & & $\begin{array}{l}\text { Group } 1(n=186) \\
\text { No stria }\end{array}$ & $\begin{array}{c}\text { Group } 2(n=82) \\
\text { Mild striae }\end{array}$ & $\begin{array}{c}\text { Group } 3(n=110) \\
\text { Severe striae }\end{array}$ & p-value \\
\hline \multirow[t]{3}{*}{ Adhesion } & Grade 0 & 125 (67\%) & $54(65 \%)$ & $70(63 \%)$ & \multirow{3}{*}{0.401} \\
\hline & Grade 1-2 & $39(21 \%)$ & $16(20 \%)$ & $27(25 \%)$ & \\
\hline & Grade 3-4 & $22(12 \%)$ & $12(15 \%)$ & $13(12 \%)$ & \\
\hline Keloid is present & & $44(24 \%)$ & $16(20 \%)$ & $19(17 \%)$ & 0.127 \\
\hline \multirow[t]{3}{*}{ Scar appearance } & Smooth & $142(76 \%)$ & $68(82 \%)$ & $86(78 \%)$ & \multirow{3}{*}{0.215} \\
\hline & Hollow & $11(6 \%)$ & $3(4 \%)$ & $11(10 \%)$ & \\
\hline & High & 33 (18\%) & $11(14 \%)$ & $13(12 \%)$ & \\
\hline
\end{tabular}

The values are presented as $n(\%)$.

\section{Discussion}

It is accepted by all surgeons that the adhesions increase as the number of surgical procedures underwent increases. Today, the rate of cesarean section increases while the rate of vaginal delivery decreases. ${ }^{[9]}$ This fact requires keeping cesarean section-related complications on the agenda all the tame. One of them is peritoneal adhesions, because the complications in association with peritoneal adhesions such as bladder and intestine injuries, infertility, chronic pelvic pain, extended surgery duration and more loss of blood may develop. ${ }^{[10]}$ When we reviewed the literature, we could not find any consistent marker predicting the severity of these adhesions. In our study, we tried to investigate this issue. The parameters such as SG scoring, the presence of keloid or scar appearance types are the non-invasive examination methods which can be assessed easily. However, we could not find any correlation between SG and the severity of peritoneal adhesions, the presence of keloid or the scar heights in our study.

We reviewed the studies performed by many authors who investigated this issue in the recent years, and by considering their limitations, we performed our study with a selected homogeneous patient group and a higher number of patients compared to the similar previous studies. We considered that ethnic origin difference may have an impact on adhesions in our country which receive high rate of immigrants, and included only Caucasian pregnant women in our study. The absence of difference between the groups in terms of age, gravida, BMI, weight gained during pregnancy, income level, educational status, weeks of gestation, fetal sex and birth weight is a significant indicator that we provided sufficient homogeneity.
According to the results of our study, there was no significant difference between SG score and peritoneal adhesions. Compared to similar previous studies, Bibi et al. in 2018 and Çelik et al. in 2018 also did not find any significant difference between SG score and peritoneal adhesions similar to our study ${ }^{[1,12]}$ Unlike other results, there are studies reporting that the severity of pelvic adhesions increase as SG score increases. ${ }^{[13-15]}$ On the other hand, there are also studies reporting that the severity of pelvic adhesions decrease as SG score increases. ${ }^{[16]}$ All these different results can be explained with the factors such as the less number of patients, different ethnic groups, different exclusion criteria, different methodologies, and different numbers of previous cesarean section.

In our study, we designed the methodology by paying attention to the limitations of the previous similar studies. We established inclusion and exclusion criteria. The population of our study was stronger than the previous similar studies. Yet, being a single-center study can be a limitation. Also, we could not provide homogeneity as we could not access any record of the surgical technique applied in the previous cesarean section of the population, and this may be another limitation of our study. By closing the uterine with single or double layers in the previous cesarean section, and whether closing the visceral and parietal peritoneum or not may be important for the development of adhesion.

\section{Conclusion}

Although the results are inconsistent in the similar studies, we believe that the score of striae gravidarum is not correlated with keloid and scar appearance, it will be an 
unsuccessful marker for the prediction of intraabdominal adhesions and that it will have low specificity values even it is used in the light of the data of our study which are stronger than the previous studies.

Conflicts of Interest: No conflicts declared.

\section{References}

1. Kılıç A, Çakmak S, Atalay C, Atıcı E, Er O, Yakut K, et al. Development of stria gravidarum in pregnant women and associated factors. [Article in Turkish] Turkderm 2015;49:95100.

2. Salter SA, Kimball AB. Striae gravidarum. Clin Dermatol 2006;24:97-100.

3. Buchanan K, Fletcher HM, Reid M. Prevention of striae gravidarum with cocoa butter cream. Int J Gynaecol Obstet 2010; 108:65-8.

4. Muallem MM, Rubeiz NG. Physiological and biological skin changes in pregnancy. Clin Dermatol 2006;24:80-3.

5. Van Der Krabben AA, Dijkstra FR, Nieuwenhuijzen M, Reijnen MM, Schaapveld M, Van Goor H. Morbidity and mortality of inadvertent enterotomy during adhesiotomy. Br J Surg 2000;87:467-71.

6. Davey CM. Factors associated with the occurrence of striae gravidarum. J Obstet Gynaecol Br Commonw 1972;79:11134.

7. Kahyaoglu I, Kayikcioglu F, Kinay T, Mollamahmutoglu L. Abdominal scar characteristics: do they predict intra-abdominal adhesions with repeat cesarean deliveries? J Obstet Gynaecol Res 2014;40:1643-8.

8. Nair SK, Bhat IK, Aurora AR. Role of proteolytic enzyme in the prevention of postoperative intraperitoneal adhesions. Arch Surg 1974;108:849-53.
9. Küçükbaş GN, Moraloğlu Ö, Özel Ş, Erkaya S, Taşcı Y, Fındık RB. The cesarean rates and indications between 2010 and 2014 in the Obstetrics Department of Dr. Zekai Tahir Burak Maternal Health Training and Research Hospital. Perinatal Journal 2016;24:61-5.

10. Awonuga AO, Fletcher NM, Saed GM, Diamond MP. Postoperative adhesion development following cesarean and open intra-abdominal gynecological operations: a review. Reprod Sci 2011;18:1166-85.

11. Bibi I, Majeed S, Hussain HN. Relation of striae gravidarum with cesarean scar and peritoneal adhesions. Journal of Medicine, Physiology and Biophysics 2018;49:107-12.

12. Celik EY, Ersoy AO, Ersoy E, Yoruk O, Tokmak A, Tasci Y. Is striae gravidarum related to cesarean scar and peritoneal adhesions? Pak J Med Sci 2018;34:568-73.

13. Abbas A. M, Khalaf M, Abdel-Reheem F, El-Nashar I. Prediction of pelvic adhesions at repeat cesarean delivery through assessment of striae gravidarum score: a cross-sectional study. Journal of gynecology obstetrics and human reproduction. J Gynecol Obstet Hum Reprod 2020;49:101619.

14. Kan O, Gorkem U, Alkilic A Cetin M. Efficacy of striae gravidarum extension and localization on predicting intraperitoneal adhesion risk. J Obstet Gynaecol Res 2019;45:2358-63.

15. Çakir Gungor AN, Oguz S, Hacivelioglu S, Isik S, Uysal A, Gencer $M$, et al. Predictive value of striae gravidarum severity for intraperitoneal adhesions or uterine scar healing in patients with previous caesarean delivery. J Mat Fet Neonatal Med 2014; 27:1312-5.

16. Dogan A, Ertas IE, Uyar I, Karaca I, Bozgeyik B, Töz E, et al. Preoperative association of abdominal striae gravidarum with intraabdominal adhesions in pregnant women with a history of previous cesarean section: a cross-sectional study. Geburtshilfe Frauenheilkd 2016;76:268-72. 